ISSN 0258-7122

Bangladesh J. Agril. Res. 38(3): 515-521, September 2013

\title{
CORRELATION AND PATH ANALYSIS OF DURUM WHEAT (Triticum turgidum L. var. Durum)
}

\author{
A. A. $\operatorname{KHAN}^{1}$, M. A. $\operatorname{ALAM}^{1}$, M. K. AlAm ${ }^{1}$ \\ M. J. ALAM ${ }^{1}$ AND Z. I. SARKER ${ }^{2}$
}

\begin{abstract}
A study was conducted to examine relationship between important traits of durum wheat and their direct and indirect effects on grain yield. Research work was conducted during the winter season of 2009-10 under irrigated optimum seeding condition at Regional Agricultural Research Station, Bangladesh Agricultural Research Institute, Ishurdi, Pabna with 10 advanced genotypes. A wheat variety was used as check. Positive and significant correlation was found for plant height, spikes $/ \mathrm{m}^{2}$, and 1000 -grain weight with grain yield. Head days and maturity days showed considerable negative correlation with grain yield. Maturity days, spikes $/ \mathrm{m}^{2}$, and 1000-grain weight had significant positive direct effects on grain yield. Grains/spike had direct positive effect but in low magnitude. The indirect effect of head days and plant height on grain yield was found mainly through maturity days and 1000-grain weight. It can be concluded that more emphasis should be given on head days and plant height along with 1000-grain weight, spikes $/ \mathrm{m}^{2}$, and grains/spike during selection for dururn wheat improvement.
\end{abstract}

Keywords: Durum wheat, correlation, path analysis, direct and indirect effects on grain yield.

\section{Introduction}

Durum wheat usually attracts a significant premium over the bread wheat grades. This and the agronomic adaptability of dururn have attracted a growing number of farmers. It is widely grown in most part of the wheat growing areas of the world. Durum wheat is a major crop in the Mediterranean basin of West Asia, North Africa, and Southern converted into pasta products. In Bangladesh, there is no durum wheat variety still now. But it is becoming an increasingly viable option to cultivate this crop in near future. This study was carried out to delineate and to generate information about durum wheat which could be important for selection during its improvement.

Success of a breeding programme depends on numerous factors. Selection of a right variety for a particular region is an important one. Yield component concept in breeding has got much importance in improving yield potentiality.

${ }^{1}$ Scientific Officer, Regional Agricultural Research Station, Bangladesh Agricultural Research Institute (BARI), Ishurdi, Pabna, ${ }^{2}$ Principal Scientific Officer, Wheat Research Centre, BARI, Nashipur, Dinajpur, Bangladesh. 
Selection based on the performance of grain yield alone, a polygenically controlled complex character, is usually not very efficient (Singh and Singh, 1973 and Sastri, 1974). Therefore, selection based on yield components was suggested to be more effective rather than yield alone (Shamsuddin and Ali, 1989). Thus, identifying and manipulating characters contributing to grain yield is important as it increases breeding efficiency. Initiating a breeding programme based on these yield components required the knowledge of relationship between yield and its component characters. In this connection, determination of correlation coefficient among the characters has considerable importance in selecting breeding materials (Afroz et al., 2004). On the other hand, path coefficient analysis has been found to give more specific information on the direct and indirect influence of each of the component characters upon grain yield. Therefore, the present study was undertaken to find out relationship between yield and its component characters and the causes of such relations was further analyzed.

\section{Materials and Method}

Eight advanced lines of durum wheat along with two cheek varieties one from $T$. durum (BDW-8) and the other from $T$ aestivum (Prodip) were evaluated at the Regional Agricultural Research Station, Ishurdi during the winter season of 2009-2010 under irrigated and optimum seeding condition. The experiment was laid out in Randomized Block Design (RBD) with four replications. The unit plot was $5 \mathrm{~m}$ long and 8 rows at $20 \mathrm{~cm}$ spacing. Pertinent data were collected from each plot on seven characters, namely days to heading, days to maturity, plant height $(\mathrm{cm})$, spikes $/ \mathrm{m}^{2}$, grains/spike, 1000-grain weight, and grain yield (kg/ha). Genotypic and phenotypic correlation coefficients were obtained as suggested by Johnson, et al. (1955) and path coefficient analysis was done as per Dewey and $\mathrm{Lu}$ (1959).

\section{Results and Discussion}

Mean value of grain yield and yield components of different characters of the advanced durum wheat lines including control are given in Table 1. Statistically significant differences among genotypes were observed for all the traits studied. Grain yield of durum wheat lines ranged between 5578 and $4469 \mathrm{~kg} / \mathrm{ha}$. D-001, D-002, and D-007 had yielded high and statistically same with control. The control variety Prodip had the tallest $(102.9 \mathrm{~cm})$ plant height. The plant height is very important in terms of resistance to lodging and harvest index (Dogan, 2009). Many researchers reported that the ideal plant height ranges from 90 to $100 \mathrm{~cm}$ (Tosun, 1987 and Yürür, 1998). It also showed the lowest head days and maturity days along with significantly high mean for rest of the characters compared to durum lines. 
Table 1. Mean performances of durum genotypes for seven different characters.

\begin{tabular}{l|lll|l|l|l|l|l}
\hline Genotype & $\begin{array}{c}\text { Head } \\
\text { days }\end{array}$ & $\begin{array}{c}\text { Maturity } \\
\text { days }\end{array}$ & $\begin{array}{c}\text { Plant } \\
\text { height } \\
(\mathrm{cm})\end{array}$ & $\begin{array}{c}\text { Spikes/m² } \\
(\text { no. })\end{array}$ & $\begin{array}{c}\text { Grains/ } \\
\text { spike } \\
(\text { no. })\end{array}$ & $\begin{array}{c}1000- \\
\text { grain } w t \\
(\mathrm{~g})\end{array}$ & $\begin{array}{c}\text { Grain } \\
\text { yield } \\
(\mathrm{kg} / \mathrm{ha})\end{array}$ \\
\hline BDW-(ch) & $77.50 \mathrm{ab}$ & $111.50 \mathrm{a}$ & $88.05 \mathrm{~cd}$ & $329.00 \mathrm{a}$ & $44.20 \mathrm{~b}-\mathrm{d}$ & $34.67 \mathrm{c}$ & $5234 \mathrm{ab}$ \\
Prodip(ch) & $69.50 \mathrm{e}$ & $103.80 \mathrm{e}$ & $102.90 \mathrm{a}$ & $312.30 \mathrm{a}-\mathrm{c}$ & $47.75 \mathrm{a}-\mathrm{d}$ & $44.50 \mathrm{a}$ & $5578 \mathrm{a}$ \\
D-001 & $75.50 \mathrm{c}$ & $109.50 \mathrm{bc}$ & $89.20 \mathrm{bc}$ & $298.00 \mathrm{a}-\mathrm{d}$ & $46.75 \mathrm{~b}-\mathrm{d}$ & $33.85 \mathrm{~cd}$ & $5125 \mathrm{a}-\mathrm{c}$ \\
D-002 & $75.75 \mathrm{bc}$ & $110.00 \mathrm{bc}$ & $90.55 \mathrm{bc}$ & $316.80 \mathrm{ab}$ & $50.25 \mathrm{ab}$ & $33.88 \mathrm{~cd}$ & $5078 \mathrm{a}-\mathrm{c}$ \\
D-003 & $77.75 \mathrm{a}$ & $109.80 \mathrm{bc}$ & $88.15 \mathrm{~cd}$ & $290.80 \mathrm{~b}-\mathrm{d}$ & $47.47 \mathrm{a}-\mathrm{d}$ & $31.85 \mathrm{~cd}$ & $4516 \mathrm{c}$ \\
D-004 & $73.50 \mathrm{~d}$ & $107.80 \mathrm{~d}$ & $85.05 \mathrm{~d}$ & $289.50 \mathrm{~b}-\mathrm{d}$ & $45.72 \mathrm{~b}-\mathrm{d}$ & $28.19 \mathrm{e}$ & $4469 \mathrm{c}$ \\
D-005 & $76.75 \mathrm{a}-\mathrm{c}$ & $108.80 \mathrm{~cd}$ & $87.60 \mathrm{~cd}$ & $287.30 \mathrm{~b}-\mathrm{d}$ & $53.25 \mathrm{a}$ & $31.21 \mathrm{~d}$ & $4906 \mathrm{bc}$ \\
D-006 & $75.75 \mathrm{c}$ & $109.00 \mathrm{c}$ & $88.05 \mathrm{~cd}$ & $279.80 \mathrm{~cd}$ & $41.53 \mathrm{~d}$ & $34.76 \mathrm{c}$ & $4906 \mathrm{bc}$ \\
D-007 & $77.75 \mathrm{a}$ & $109.30 \mathrm{c}$ & $92.05 \mathrm{~b}$ & $300.50 \mathrm{a}-\mathrm{d}$ & $43.05 \mathrm{~cd}$ & $33.24 \mathrm{~cd}$ & $4969 \mathrm{a}-\mathrm{c}$ \\
D-008 & $78.50 \mathrm{a}$ & $110.80 \mathrm{ab}$ & $88.05 \mathrm{~cd}$ & $269.80 \mathrm{~d}$ & $48.03 \mathrm{a}-\mathrm{c}$ & $38.03 \mathrm{~b}$ & $4859 \mathrm{bc}$ \\
\hline
\end{tabular}

D: Advanced Durum Wheat Line

Means of the same column followed by the same letter do not differ significantly at $5 \%$ level of probability

The phenotypic and genotypic correlation coefficients determined among the characteristics are presented in Table 2. The genotypic correlation coefficients were higher than their corresponding phenotypic ones in most of the cases which indicated that the association was largely due to genetic factors. It can also be mentioned that genotypic potentiality can easily be modified based on these desirable results.

Table 2. Genotypic $\left(r_{g}\right)$ and phenotypic $\left(r_{p}\right)$ correlation coefficients among yield and other components in durum wheat.

\begin{tabular}{|c|c|c|c|c|c|c|c|}
\hline Character & & $\begin{array}{c}\text { Maturity } \\
\text { days }\end{array}$ & $\begin{array}{l}\text { Plant } \\
\text { height }\end{array}$ & $\begin{array}{c}\text { No. of } \\
\text { spikes/ } \\
\mathrm{m}^{2}\end{array}$ & $\begin{array}{l}\text { No. of } \\
\text { grains/ } \\
\text { spike }\end{array}$ & $\begin{array}{l}\text { 1000- } \\
\text { grain } \\
\text { wt }\end{array}$ & $\begin{array}{l}\text { Grain } \\
\text { yield }\end{array}$ \\
\hline \multirow[t]{2}{*}{ Head days } & $r_{g}$ & $0.956 * *$ & $-0.701 *$ & -0.274 & -0.111 & -0.489 & -0.504 \\
\hline & $r_{p}$ & $0.810 * *$ & $-0.632 *$ & -0.260 & 0.039 & -0.418 & -0.411 \\
\hline \multirow[t]{2}{*}{ Maturity days } & $r_{g}$ & & $-0.784 * *$ & -0.099 & -0.147 & -0.520 & -0.455 \\
\hline & $r_{p}$ & & $-0.657 *$ & 0.011 & -0.028 & -0.393 & -0.250 \\
\hline \multirow[t]{2}{*}{ Plant height } & $r_{g}$ & & & 0.390 & 0.047 & $0.883 * *$ & $0.936 * *$ \\
\hline & $r_{p}$ & & & 0.416 & 0.065 & $0.741 *$ & 0.587 \\
\hline \multirow[t]{2}{*}{ Spikes $/ \mathrm{m}^{2}$} & $r_{g}$ & & & & -0.180 & 0.258 & $0.742 *$ \\
\hline & $r_{p}$ & & & & 0.137 & 0.097 & 0.459 \\
\hline \multirow[t]{2}{*}{ Grains/ spike } & $r_{g}$ & & & & & -0.032 & -0.015 \\
\hline & $r_{p}$ & & & & & 0.020 & 0.071 \\
\hline \multirow[t]{2}{*}{1000 -grain wt } & $r_{g}$ & & & & & & $0.99 * *$ \\
\hline & $r_{p}$ & & & & & & 0.539 \\
\hline
\end{tabular}

$*$ and $* *$ Significant at $5 \%$ and $1 \%$ levels of probability, respectively. 
More importantly, grain yield was positively associated with plant height, spikes $/ \mathrm{m}^{2}$ and 1000 -grain weight both at genotypic and phenotypic levels where the association was found significant at genotypic level only. Nofouzi et al. (2008) also reported significant and positive correlation between grain yield and plant height. Moreover, significant and positive correlation among number of productive tillers per plant and grain yield was noticed by Ali et al. (2008) in wheat. This result was also corroborated with the findings of Dogan (2009) and Gashaw et al. (2007). They had reported significant and positive correlation between grain yield and 1000-grain weight. Days to heading and days to maturity displayed a non-significant genotypic and phenotypic correlation with yield and with 1000-grain weight but their correlation were considerably high and negative. Similar results of non-significant and negative association of grain yield and maturity was observed by Subhashchandra et al. (2009) and Gashaw et al. (2007). It indicated that due to increase of vegetative phase, the opportunity for fixation of photosynthates and its translocation to developing grains was also short causing significant reduction of grain yield and grain size. The correlations of grains/spike with grain yield, and 1000-grain weight was negative at genotypic level and low in magnitude indicated that higher grain number adversely affect grain size which ultimately reduced grain yield.

Plant height showed significant and positive correlation with 1000-grain weight at both genotypic and phenotypic levels. It was also positively associated with number of spikes $/ \mathrm{m}^{2}$ and number of grains/spike. On the contrary, it was found negative and significant at both levels with head days suggesting that tall plants showed low head days resulting longer reproductive phase which accumulated more photosynthates to the grain. Apparently, this situation suggested highly significant positive correlation between plant height and grain yield. Similar findings were reported by Shamsuddin and Ali (1989) in wheat. Plant height also showed significant and negative association with maturity days which supports the findings noticed by Subhashchandra et al. (2009). Days to maturity showed considerable negative correlation for all the traits studied. Considerable negative correlations were also observed for head days with all the traits except maturity days suggesting shorter vegetative phase along with longer reproductive phase to contribute higher grain yield.

The path coefficient analysis appeared to provide a clue to the contribution of various components of yield to overall grain yield of the genotypes under study. It also provided an effective way of finding out direct and indirect sources of correlation. In our study of path coefficient analysis, grain yield represented the dependent variable and days to heading, days to maturity, plant height, number of spikes $/ \mathrm{m}^{2}$, number of grains/spike, 1000-grain weight were the independent ones. Direct and indirect effects of these components determined on grain yield and their contribution ratios were summarized in Table 3. 
The results of path coefficient analysis for genotypic correlations among the traits revealed that 1000-grain weight exerted the highest direct positive effect (0.661) on grain yield followed by maturity days (0.594), number of spikes/ $\mathrm{rn}^{2}$ (0.392) and number of grains/spike (0.107). Yagdi (2009) noticed that 1000kernel weight increased the yield with the direct effect value of 0.286. Direct effect of spikes $/ \mathrm{m}^{2}$ had a proportion of $43.75 \%$ positive. This result partially supports the findings of Subhashchandra et al. (2009) and Ali el al. (2008) for the direct effect of productive tillers/plant on grain yield. Dogan (2009) had reported direct positive effect for grain number/spike and 1000-grain weight on yield. Ali et al. (2008) suggested that preference must be given on the number of productive tillers/plant and number of grains/spike in selection along with optimum plant height to select superior wheat genotypes.

Table 3. Path analysis of different characters on yield of durum wheat.

\begin{tabular}{|c|c|c|c|c|c|c|c|c|}
\hline \multirow{2}{*}{\multicolumn{2}{|c|}{ Character }} & \multicolumn{6}{|c|}{ Effect via } & \multirow{2}{*}{$\begin{array}{l}\text { Total } \\
\text { genotypic } \\
\text { correlation } \\
\left(\mathrm{r}_{\mathrm{g}}\right) \text { with } \\
\text { grain yield }\end{array}$} \\
\hline & & \multirow{2}{*}{$\begin{array}{c}\begin{array}{c}\text { Head } \\
\text { days }\end{array} \\
\mathbf{- 0 . 3 2 7}\end{array}$} & \multirow{2}{*}{\begin{tabular}{|l}
$\begin{array}{c}\text { Maturity } \\
\text { days }\end{array}$ \\
0.567
\end{tabular}} & \multirow{2}{*}{$\begin{array}{c}\begin{array}{c}\text { Plant } \\
\text { height }\end{array} \\
-0.302\end{array}$} & \multirow{2}{*}{\begin{tabular}{|c|c}
$\begin{array}{c}\text { No. of } \\
\text { spikes/ } \\
\mathrm{m}^{2}\end{array}$ \\
-0.107
\end{tabular}} & \multirow{2}{*}{\begin{tabular}{|c}
$\begin{array}{c}\text { No. of } \\
\text { grains/ } \\
\mathrm{m}^{2}\end{array}$ \\
-0.012
\end{tabular}} & $\begin{array}{c}\text { 1000- } \\
\text { grain } \\
\text { wt }\end{array}$ & \\
\hline Head & $(\mathrm{P})$ & & & & & & -0.323 & -0.504 \\
\hline days & $(\%)$ & 19.96 & 34.62 & 18.44 & 6.53 & 0.73 & 19.72 & \\
\hline Maturity & $(\mathrm{P})$ & -0.313 & 0.594 & -0.337 & -0.039 & -0.015 & -0.343 & -0.455 \\
\hline days & $(\%)$ & 19.07 & 36.20 & 20.54 & 2.38 & 0.91 & 20.90 & \\
\hline Plant & (P) & 0.229 & -0.465 & 0.431 & 0.153 & 0.005 & 0.583 & $0.936 * *$ \\
\hline height & $(\%)$ & 12.27 & 24.92 & 23.10 & 8.20 & 0.27 & 31.24 & \\
\hline Spikes/ & (P) & 0.089 & -0.058 & 0.168 & 0.392 & -0.019 & 0.170 & $0.742 *$ \\
\hline $\mathrm{m}^{2}$ & $(\%)$ & 9.93 & 6.47 & 18.75 & 43.75 & 2.12 & 18.97 & \\
\hline Grains/ & (P) & 0.036 & -0.087 & 0.020 & -0.071 & 0.107 & -0.021 & -0.015 \\
\hline spike & $(\%)$ & 10.53 & 25.44 & 5.85 & 20.76 & 31.29 & 6.14 & \\
\hline $1000-$ & (P) & 0.159 & -0.309 & 0.380 & 0.101 & -0.003 & 0.661 & $0.99 * *$ \\
\hline grain wt & $(\%)$ & 9.86 & 19.16 & 23.56 & 6.26 & 0.19 & 40.98 & \\
\hline
\end{tabular}

Residual effect $=\sqrt{ }-0.241$

Bold figures in diagonal line indicate direct effect

$\mathrm{P}=$ Path coefficient; $\%=$ Percentage of direct and indirect effects

* and ** Indicate 5\% and $1 \%$ level of probability, respectively.

Number of spikes $/ \mathrm{m}^{2}$ had indirect significant effect via 1000-grain weight and plant height in positive direction and its high direct effect on grain yield. The contribution of these indirect effects was 18.97 and $18.75 \%$, respectively. Number of grains/spike exhibited high indirect effect in negative direction via maturity days, while 1000-grain weight showed positive direction via plant 
height, besides their direct effects at high level in positive direction. Percentages of these indirect effects were 25.44 and $23.56 \%$, respectively. Maturity days showed considerable negative indirect effect via 1000- grain weight, plant height and head days, while its direct effect at high level in positive direction caused non-significant negative effects between maturity days and grain yield. Head days had the highest positive indirect effect $(34.62 \%)$ via maturity days on yield, while plant height via 1000-grain weight $31.24 \%$. Head days showed considerable negative direct effects $(-0.327)$ on yield. Furthermore, plant height showed considerable positive direct effect on yield as $23.1 \%$. Ashraf et al. (2002) found that direct effect of plant height on grain yield/plant was positive. Such results were also reported by Dogan (2009) in durum wheat.

From the correlation and path coefficient analyses, it can be summarized that more emphasis should be given on head days and plant height along with 1000grain weight, number of spikes $/ \mathrm{m}^{2}$ and number of grains/spike could be useful selection criteria for durum wheat breeding. Many of earlier studies (Kumar and Hunshal, 1998; Garcia et al., 2003; Ali et al., 2008; Dogan, 2009; and Subhashchandra et al., 2009) indicated that plant height, spikes $/ \mathrm{m}^{2}$, grains/spike, and 1000-grain weight are the main contributors to grain yield in durum wheat which supports the present findings. The above results also permit for further study of evolving desirable materials of durum wheat.

\section{References}

Afroz, R., M. S. H. Sharif and L. Rahman. 2004. Genetic variability, correlation and path analysis in mustard and rape (Brassica spp.). Bangladesh J. P1. Breed. Genet. 17(1): 59-63.

Ali, Y., B. M. Atta, J. Akhter, P. Monneveux and Z. Lateef. 2008. Genetic variability, association and diversity studies in wheat (Triticum aestivum L.) germplasm. Pak J. Bot. 40(5): 2087-2097.

Ashraf, M., A. Ghafoor, N. A. Khan and M. Yousaf. 2002. Path coefficient in wheat under rainfed conditions. Pakistan J. Agric. Res. 17: 1-6.

Dewey, D. R. and K. H. Lu. 1959. A correlation and path-coefficient analysis of components of crested wheatgrass grain production. Agronomy Journal 51: 515-518.

Dogan, R. 2009. The correlation and path coefficient analysis for yield and some yield components of durum wheat (Triticum turgidum L. var. Durum) in west anatolia conditions. Pak. J. Bot. 41(3): 108 1-1089.

Elias, E. M. and F. A. Manthey. 2005. End products. In: Royo, C., M. N. Nachit, N. Di fonzo, J. L. Araus, W. H. Pfeiffer and G. A. Slafer, eds. Durum wheat breeding. Current approaches and future strategies. New York: Food Academic Press, The Haworth Press, 63-86. 
Garcia, L. F., Y. del Moral, D. Rharrabti, Villagas and C. Royo. 2003. Evaluation of grain yield and its components in durum wheat under Mediterranean conditions. Agronomy Journal. 95: 266-274.

Gashaw, A., H. Mohammed and H. Singh. 2007. Selection criterion for improved grain yields in Ethiopian durum wheat genotypes. African Crop Sci. J. 15(1): 25-31.

Johnson, H. W., H. F. Robinson and R. E. Comstock. 1955. Estimation of genetic and environmental Variability in soybean. Agronomy Journal 47: 314-318.

Kumar, B. N. A. and C. S. Hunshal. 1998. Correlation and path coefficient analysis in durum wheats (Triticum durum Desf.) under different planting dates. CropResearch-Hisar. 16(3): 358-361.

Nofouzil, F., V. Rashidi and A. R. Tarinejad. 2008. Path analysis of grain yield with its components in durum wheat under drought stress. International meeting on soil fertility land management and agroclimatology. Turkey. P. 681-686.

Sastri, A. B. 1974. Path analysis of yield components in tobacco. Indian J Genet. 34: 57-58.

Shamsuddin, A. K. M. and M. M. Ali. 1989. Genotypic and phenotypic correlation and path analysis in spring wheat. Bangladesh J. Agril. Sci. 16(1): 75-78.

Singh, T. P. and K. B. Singh. 1973. Association of grain yield and its components in segregating populations of green gram. Indian J. Genet. 33: 112-117.

Subhashchandra, B., H. C. Lohithaswa, S. A. Desai, R. R. Hanchinal, I. K. Kalappanavar, K. K. Math and P. M. Salimath. 2009. Assessment of genetic variability and relationship between genetic diversity and transgressive segregation in tetraploid wheat. Karnataka J. Agric. Sci. 22(1):36-38.

Tosun, O. 1987. Türkiye'nin Tahil Yetiştirme Sorunları ve Bunlarin Çözüm Yolları. Türkiye Tahıl Simpozyumu (Tübitak), Bursa.

Yagdi, K. 2009. Path coefficient analysis of some yield components in durum wheat (Triticum durum desf.). Pak J. Bot. 41(2): 745-751.

Yürür, N. 1998. Serin Iklim Tahillari (Tahillar-I). U.Ü. Basimevi, 171-172. 